\title{
Effects of bottom fishing on the benthic megafauna of Georges Bank
}

\author{
Jeremy S. Collie ${ }^{1, *}$, Galo A. Escanero ${ }^{1}$, Page C. Valentine ${ }^{2}$ \\ ${ }^{1}$ Graduate School of Oceanography, University of Rhode Island, Narragansett, Rhode Island 02882, USA \\ ${ }^{2}$ United States Geological Survey, Woods Hole, Massachusetts 02543, USA
}

\begin{abstract}
This study addresses ongoing concerns over the effects of mobile fishing gear on benthic communities. Using side-scan sonar, bottom photographs and fishing records, we identified a set of disturbed and undisturbed sites on the gravel pavement area of northern Georges Bank in the northwest Atlantic. Replicate samples of the megafauna were collected with a $1 \mathrm{~m}$ Naturalists' dredge on 2 cruises in 1994 . Compared with the disturbed sites, the undisturbed sites had higher numbers of organısms, biomass, species richness and species diversity; evenness was higher at the disturbed sites. Undisturbed sites were characterized by an abundance of bushy epifaunal taxa (bryozoans, hydroids, worm tubes) that provide a complex habitat for shrimps, polychaetes, brittle stars, mussels and small fish. Disturbed sites were dominated by larger, hard-shelled molluscs, and scavenging crabs and echinoderms. Many of the megafaunal species in our samples have also been identified in stomach contents of demersal fish on Georges Bank; the abundances of at least some of these species were reduced at the disturbed sites.
\end{abstract}

KEY WORDS: Benthic communities Fishing impacts - Habitat disturbance - Scallop dredging

\section{INTRODUCTION}

As long as mobile fishing gear has been used, there have been concerns over its harmful effects on benthic habitats (De Groot 1984). Ways in which gear directly affects the sea bed can be classified as scraping or ploughing, sediment resuspension, physical destruction of bedforms, and removal or scattering of non-target benthos. Delayed effects on the sea bed include post-fishing mortality of organisms and long-term changes to the benthic community structure (Jones 1992). A committee of the U.S. National Research Council identified fishing as the most ubiquitous agent of change in marine biodiversity (NRC 1995). Although the effect of 1 passage of a fishing net is relatively minor, the cumulative effect and the intensity of trawling and dredging may generate long-term changes in benthic communities. A substantial proportion of the sea bottom may be covered with trawl or dredge tracks

•E-mail: jcollie@limanda.gso.uri.edu in intensively fished areas (Caddy 1973, Messieh et al. 1991), with some areas being fished several times per year (Churchill 1989, Auster et al. 1996).

Early studies (Alexander et al. 1914, Graham 1955) evaluated the impacts of bottom trawling by examining damage to organisms caught by the trawl itself. However, to detect changes to a community or ecosystem, it is necessary to use fishery-independent sampling devices such as benthic samplers and underwater photography. Some studies have been conducted on previously trawled grounds, where the community structure may have been altered already. To quantify the effects of disturbance, one must use an experimental approach that compares trawled and untrawled sites (Van Dolah et al. 1987, Riemann \& Hoffman 1991) and/or has a before-and-after design (Peterson et al. 1987. Sainsbury 1988).

A common approach is to conduct experimental trawling or dredging in areas closed to bottom fishing (e.g. Thrush et al. 1995). This experimental design allows control-treatment comparisons to be made before and after the experimental fishing. One such study 
on the Grand Bank of Newfoundland documented that trawling can homogenize sediments to a depth of at least $4.5 \mathrm{~cm}$ (Schwinghamer et al. 1996). Experimental beam trawling in the Irish Sea reduced species richness by $50 \%$ and decreased the mean abundance of some taxa (Kaiser \& Spencer 1996). A limitation of these experiments is that they do not measure the long-term effects of chronic fishing disturbance.

The effects of bottom fishing depend on the type of sediment and the resident fauna. Megafaunal species (e.g molluscs, shrimps, etc. $>10 \mathrm{~mm}$ ) are in general more vulnerable to fishing effects than macrofaunal species because they are slow growing and take a long time to recuperate from disturbance or harvesting. Emergent and sessile species are the most vulnerable of the benthic megafauna, especially those that are non-retractile (Van Dolah et al. 1987). Emergent epifauna (e.g. sponges, hydroids, bryozoans) provide habitats for invertebrates and fishes; destruction of this habitat has been linked to bottom fishing (Reise 1982, Langton \& Robinson 1990, Auster et al. 1996) In Tasman Bay, New Zealand (Bradstock \& Gordon 1983), and on the northwest Australian shelf (Sainsbury 1988), areas with emergent epifauna were closed to trawling to preserve fish stocks. If recovery is not permitted, the changes in community structure (e.g. decrease in diversity) may be permanent (Jones 1992).

Georges Bank is a shallow ( 3 to $150 \mathrm{~m}$ water depth), elongate extension of the northeastern U.S. Atlantic continental shelf east of New England (Fig 1). Cover-

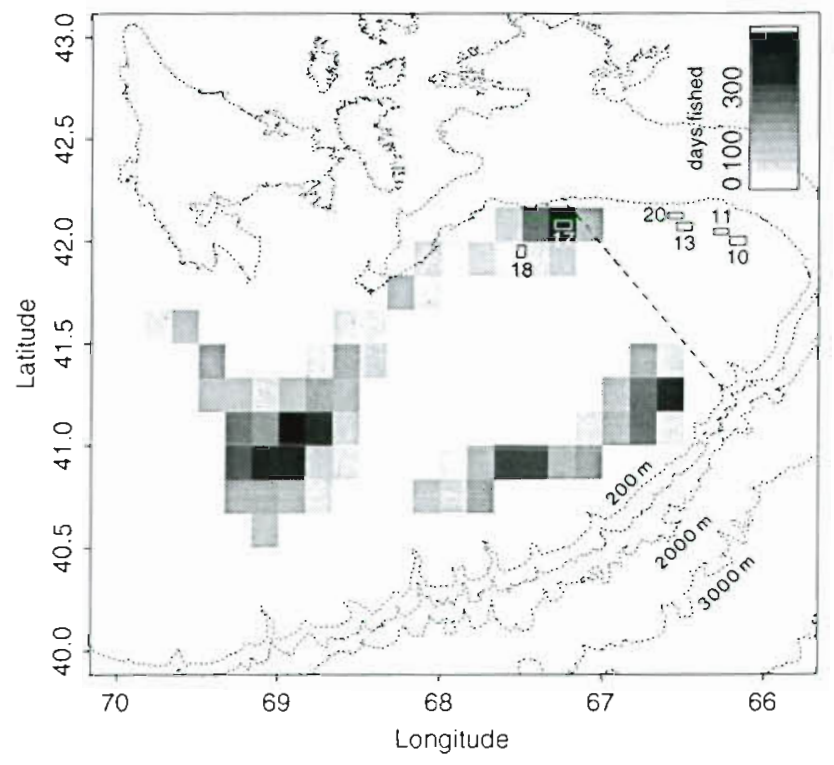

Fig. 1. Spatial distnbution of scallop dredging effort in U.S. waters in 1993. Also shown are the 6 sites sampled on cruises in April and November 1994, and the international boundary between the U.S. and Canadian Exclusive Economic Zones (broken line) ing an area of approximately $40000 \mathrm{~km}^{2}$, it is bounded on the north by the deeper waters of the Gulf of Maine and on the south by the Atlantic Ocean. The bank is eroding, and no sediment is transported to it from the continent or from adjacent shelf regions. Glacial debris covers the bank, from which sand is winnowed and transported into deep water by storm currents and by strong semi-diurnal tidal currents that reach maximum speeds of $1 \mathrm{~m} \mathrm{~s}^{-1}$ on the sea bed (Moody et al. 1984)

Since the retreat of glaciers, the surficial sediments of Georges Bank have been reworked by the actions of a rising sea and tidal and storm currents. As a result, sediment texture varies greatly on the bank, ranging from very coarse gravel to sand (Valentine et al. 1993). In sandy, shallow areas ( 3 to $50 \mathrm{~m}$ water depth), strong tidal and storm currents have constructed large dunes and sand ridges. On the northeastern part of the bank, currents have transported sand into deep water, leaving behind a thin gravel pavement that extends $150 \mathrm{~km}$ along the northern edge and covers more than $3000 \mathrm{~km}^{2}$ This pavement includes several areas of rough sea floor with scattered boulders that constitute fishing hazards. In deeper areas of the bank, bottom currents and sediment movement are slower, and the sea bed is smoother and finer grained.

Sea-floor sediments are key determinants of biological habitats on the northwest Atlantic continental shelf (Langton et al. 1995). Previous studies have revealed important relationships between fishery species and the sedimentary environment of Georges Bank (Valentine \& Lough 1991). For instance, in late July and August, demersal cod juveniles are present only in the gravel habitat on eastern Georges Bank (Lough et al. 1989). These observations, made over several years, suggest that juvenile cod are best able to avoid predators and to find prey on the gravel sea bed, and that this habitat is essential for their survival and recruitment to the fishery.

The historic herring spawning grounds on eastern Georges Bank are located where the strongest tidal. currents flow over the gravel pavement, producing a unique environment where the eggs can become attached to a firm substrate and hatch in clean, oxygenated water This habitat is limited to the shallow, western part of the gravel sea bed betwcen $67^{\circ} 10^{\prime} \mathrm{W}$ and $67^{\circ} 35^{\prime} \mathrm{W}$ longitude on the bank's northern edge (Valentine \& Lough 1991). Sea scallops Placopecten magellanicus on eastern Georges Bank are most abundant on gravel or gravelly sand habitats; they are almost absent from shallow sandy areas with strong tidal and storm currents and mobile sand waves and ripples (Thouzeau et al. 1991.a). Scallop distribution appears to be related to an inability of juveniles to colonize areas of the bank where strong currents and shifting sand might bury them or clog their feeding apparati. 
On the northern edge of Georges Bank, both otter trawls and scallop dredges are used for bottom fishing Both types of gear disturb the sea bed in a persistent directly observable fashion, but scallop dredges are heavier than trawls, with more area penetrating the bottom (Jones 1992). In this paper, we refer to areas with high levels of bottom fishing as disturbed, and areas with little or no bottom fishing as undisturbed. Tracks of dredges and trawl doors on the gravel pavement can be identified (with side-scan sonar and submersibles) by low gravel mounds and by the cleaner surfaces of gravel particles due to abrasion of attached organisms (see Fig 2). Undisturbed gravel is covered with calcareous wrorm tubes and other attached organisms (Valentine \& Lough 1991). In addition to dredging disturbance, sediment type and depth are the 2 main factors regulating the distribution of megabenthos (animals $>10 \mathrm{~mm}$ ) on eastern Georges Bank (Thouzeau et al. 1991b). The highest species diversity and biomass documented was on 'biogenic bottoms', which presumably had not been disturbed by fishing gear

We have initiated a multi-year study of the effects of bottom fishing on benthic megafaunal communities in the gravel habitat on the northern edge of Georges Bank. The study was motivated by concerns that factors in addition to overfishing may contribute to the depletion of demersal fish stocks, and by the increasing consideration of habitat in amending U.S. fishery management plans. In 1994 we conducted 2 cruises on the northern edge of Georges Bank in U.S. and Canadian waters. The cruise objective was to quantify the differences between disturbed and undisturbed sites. Each site was surveyed with side-scan sonar and photographic transects; the benthic fauna was sampled with a Naturalists' dredge. In this paper we report on the results of the megafaunal analyses from the 2 cruises; the photographic analyses form the basis of another paper (Collie et al. 1996)

\section{METHODS}

The samples for this study were collected during 2 cruises to northern Georges Bank: the first aboard NOAA Ship 'Albatross IV' from 6 to 15 April 1994; the second aboard NOAA Ship 'Delaware II' from 8 to 18 November 1994 . Six study sites (approximately $5 \times$ $10 \mathrm{~km}$; Fig 1) were selected from areas of gravel pavement identified from sediment maps (Valentine et al. 1993). The sites were chosen to provide contrasting levels of disturbance at similar depths and similar sediment compositions

Three types of information were used to assess the degree of bottom disturbance. A $100 \mathrm{kHz}$ high-resolution side-scan sonar survey was made of each site.
Overlapping sonar transects were made such that the total area surveyed at each site was approximately $10 \mathrm{~km}^{2}$. The sonograms were examined to determine sediment roughness and the degree of bottom disturbance, as indicated by visible trawl and dredge tracks. Each site was also surveyed with 15 min video transects of the sea floor to identify stations for benthic sampling. Generally, 3 video transects were made at each site; a still camera was also used on the November cruise. The presence or absence of epifauna in the videos gave a second measure of the degree of disturbance. A third measure of bottom disturbance was obtained from records of scallop dredging effort in U.S. territory, collected by the Northeast Fisheries Science Center (NOAA). The effort data are classified by $10^{\prime} \times$ $10^{\prime}$ quadrants, thereby indicating the spatial distribution of dredging effort. These $10^{\prime}$ quadrants are much coarser than our sampling resolution but they do indicate the broad distribution of scallop dredging

Within each site, 1 to 3 stations were selected for benthic sampling, and at least 3 replicate samples were collected at each station. Station locations were selected to be representative of the site and to provide contrast between disturbed and undisturbed sites. Benthic samples were obtained with a $1 \mathrm{~m}$ wide dredge similar to the design illustrated by Eleftheriou \& Holme (1984, p 152). The dredge was fitted with a $6.4 \mathrm{~mm}$ square mesh liner to catch megafauna. Tow duration was short ( 30 to $45 \mathrm{~s}$ ) to avoid overfilling the bag with gravel and losing the sample. The beginning and end locations of each tow were determined with differential GPS (global positioning system).

Once the sample was brought on deck, organisms were manually picked from the gravel and collected in tubs of seawater Samples containing a very large volume of gravel were subsampled. Stations with markedly different sediments (e.g high percentage of sand) were excluded from this analysis. Sediment volume was measured by shoveling the gravel into $9 \mathrm{l}$ buckets. One 9 l subsample of the sediment from each sample was sieved over a $5 \mathrm{~mm}$ screen to collect any organisms that were overlooked during manual picking; this subsample was later scaled to the total volume sampled. Selected specimens were photographed on board to aid in species identification. The samples were preserved in $10 \%$ buffered formalin in seawater

In the laboratory, the samples were sorted and identified to the lowest taxonomic level possible. The wet weight of each taxon was determined $( \pm 1 \mathrm{mg})$ after blotting. We measured the individual sizes of selected species that were abundant at disturbed and undisturbed sites with vernier calipers. Prior to data analysis, the species lists were screened to remove species that were not quantitatively sampled by the Naturalists' dredge. These included colonial animals 
(e.g. sponges, bryozoans, hydroids, and the polychaete Filograna implexa) and animals that would not be consistently retained by the $6.4 \mathrm{~mm}$ mesh liner (e.g amphipods).

Data analysis. Five aggregate ecological indices were calculated for each sample. Numerical abundance and biomass were standardized per unit volume of sediment and transformed to normalize their distributions. The appropriate Box-Cox transformation for each index was determined by constructing a quantile-quantile plot and comparing the correlation coefficient with a critical value (Johnson \& Wichern 1992). Species diversity has 2 components: the number of species (S) and the distribution of individuals among the species. The Shannon-Wiener diversity index $\left(H^{\prime}\right)$ includes both these components; we calculated $H^{\prime}$ with base-2 logarithms. The evenness diversity index was computed as $2^{H^{\prime}} / \mathrm{S}$ (Buzas \& Gibson 1969). Species richness was standardized by the rarefaction method (Krebs 1989). Bartlett's method (Sokal \& Rohlf 1981) was used to test for homogeneity of variances among the stations

One-way analysis of variance (ANOVA) was performed to test for significant differences between the means of the ecological indices among stations and sites. Two-way ANOVA was performed to test for significant differences in the means of the ecological indices from sites at 2 depths ( 40 and $80 \mathrm{~m}$ ) and with 2 disturbance levels (disturbed and undisturbed). Twoway ANOVAs were calculated separately for each cruise, and then a 3-way ANOVA was performed with cruise as the third factor.

We classified the species compositions of the samples with Two-Way Indicator Species Analysis (TWINSPAN) This multivariate method involves a primary ordination of the samples by correspondence analysis. Divisions near the midpoint of each principal axis from each successive analysis serve to contrast the most dissimilar object types. TWINSPAN classifies the samples according to their species composition, then uses this classification to sort the species according to their ecological preferences. The 2 classifications are then used together to obtain an ordered 2-way table that expresses the species synecological relations (Hill 1979). The TWINSPAN table arranges stations and species along the major gradients within the data. Abundance or biomass values are not used directly but are converted to an arbitrary importance scale
Size distributions of abundant species were compared between samples with the 2-sample Kolmogorov-Smirnov test. This method tests if the maximum difference between the cumulative relative frequency distributions of the 2 samples is significant (Sokal \& Rohlf 1981). We used size classification intervals of 1,2 , and $5 \mathrm{~mm}$ to check whether the results of the tests were sensitive to the size interval.

\section{RESULTS}

Six sites were sampled: 2 in the U.S. zone and 4 in the Canadian zone (Fig 1, Table 1). Sites 10, 11 and 20 are located in areas where relict boulders are obstacles to dredging and trawling. The sediment is predominantly pebble/cobble with a high percent cover of the tube-dwelling polychaete Filograna implexa (Fig. 2). The presence of these very brittle, calcareous tubes indicated a lack of disturbance. Dredge tracks were visible as dark lines on the side-scan sonograms. There was some minor evidence of dredging at Sites 10 and 11, particularly on the eastern side of Site 10. Sites 13 and 17 were heavily disturbed. The sediment was smooth pebbles, almost devoid of encrusting organisms such as F. implexa. Site 18 appeared undisturbed even though there were very few boulders that would be obstacles to dredging

At present, dredging effort data are available to us from the U.S. zone only. Total dredging effort increased dramatically during the 1980 s (NOAA, Northeast Fisheries Science Center). The quadrant containing Site 17 had the highest dredging effort in 1993 (Fig 1); the quadrant containing Site 18 had lower dredging effort. There is likely to be considerable spa-

Fig. 2 (facing page). (iruvel habitat on eastern Georges Bunk in November 1994. The area shown in each photograph has approximate dimensions of $7.5 \times 50 \mathrm{~cm}$, and the gravel particles range up to $5 \mathrm{~cm}$ in size. (A) Gravel pavement in an undisturbed area (Site 10) with abundant tubes of the worm Filograna implexa. (B) Gravel pavement in a disturbed area (Site 13) with few attached organisms. Photographed by Dann Blackwood, USGS 


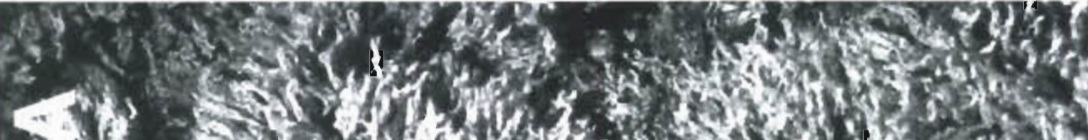

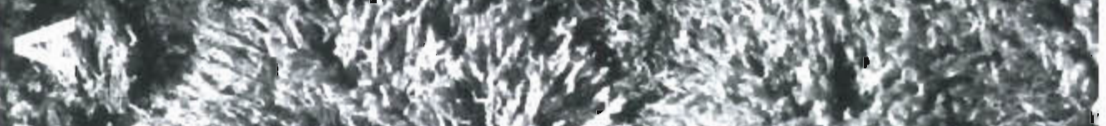

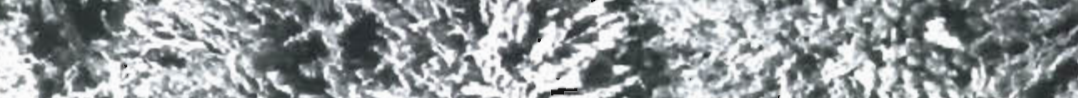

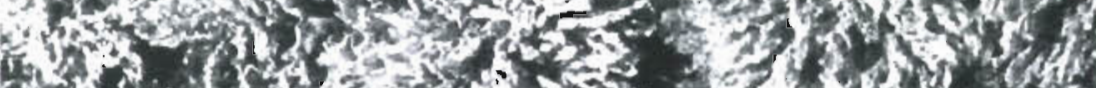

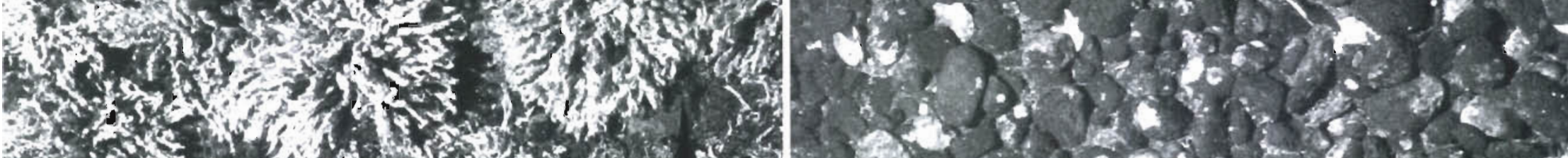

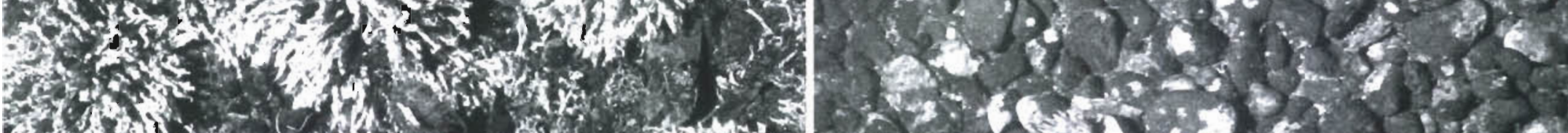

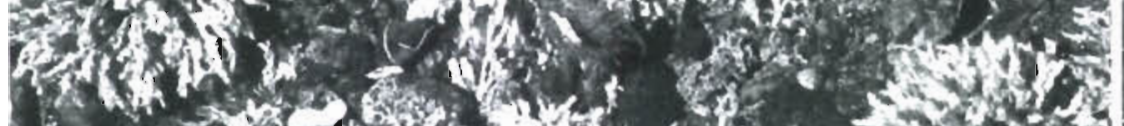

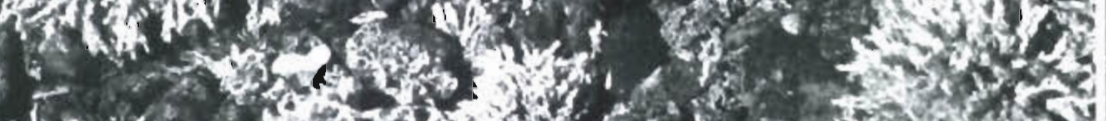

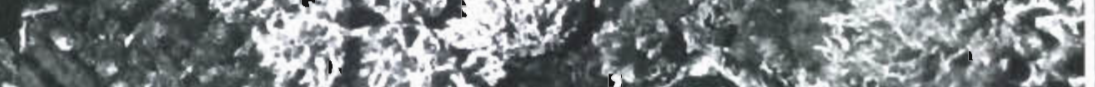

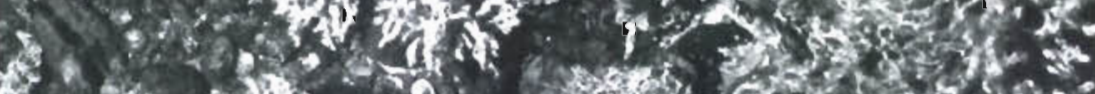

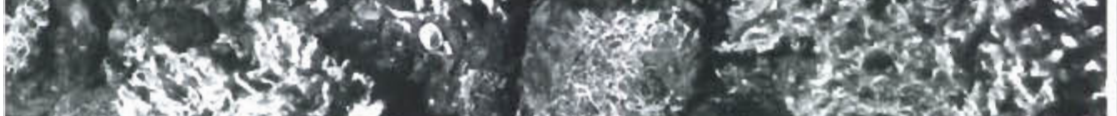
If

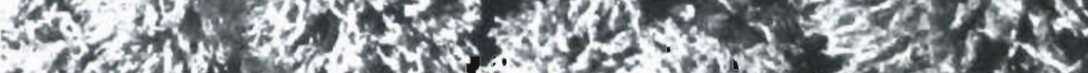

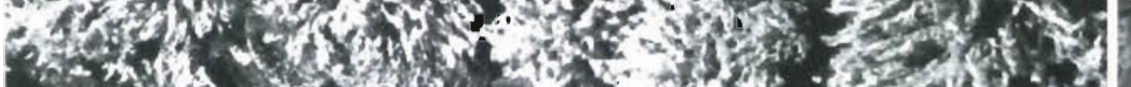

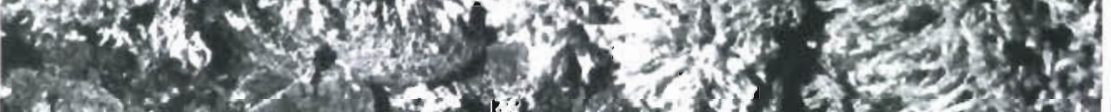

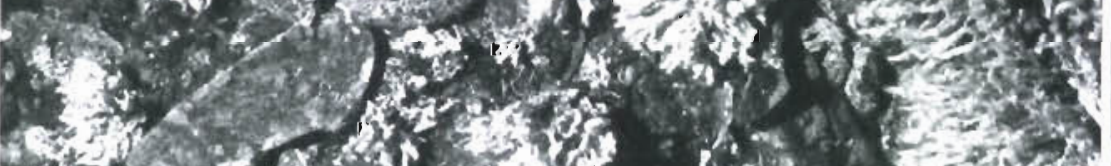

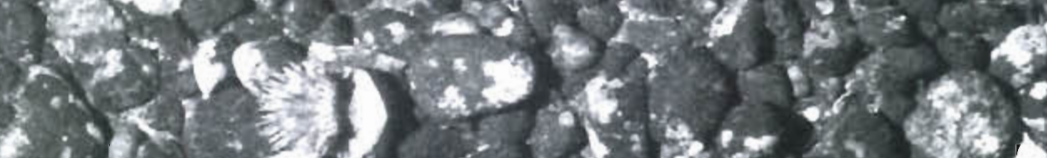
8.

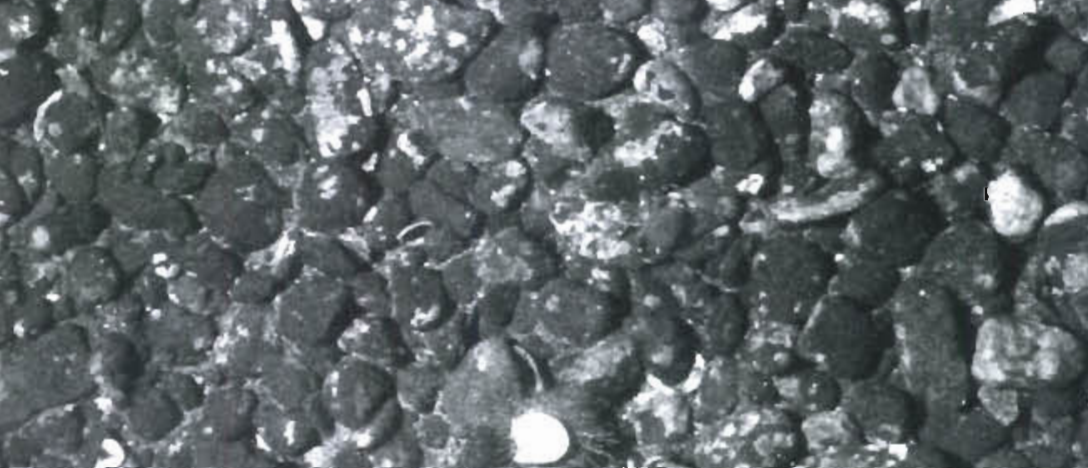

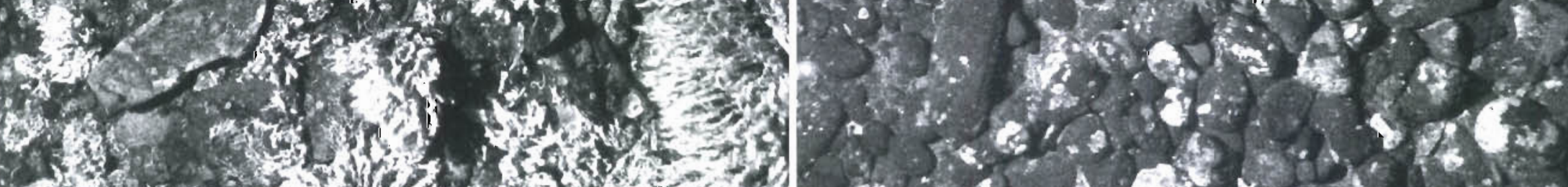

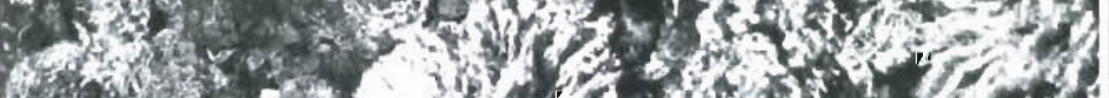

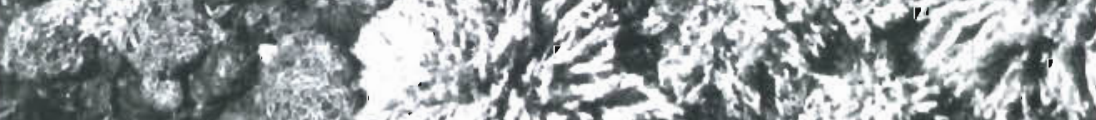

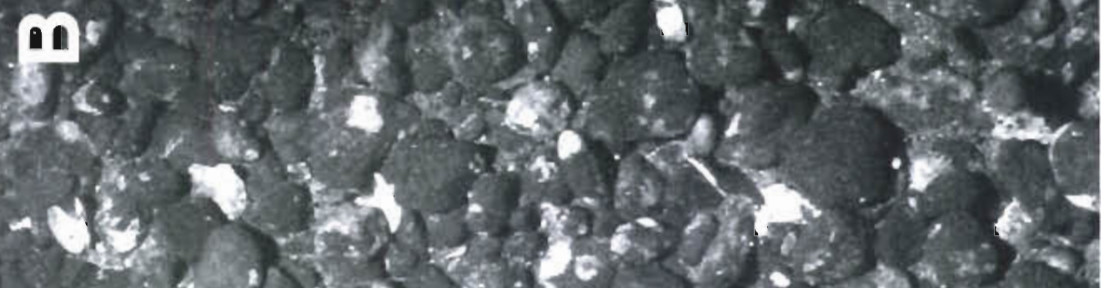

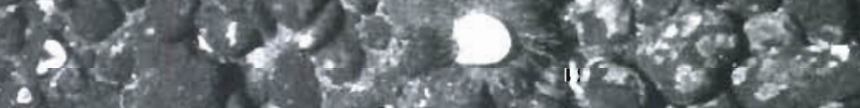

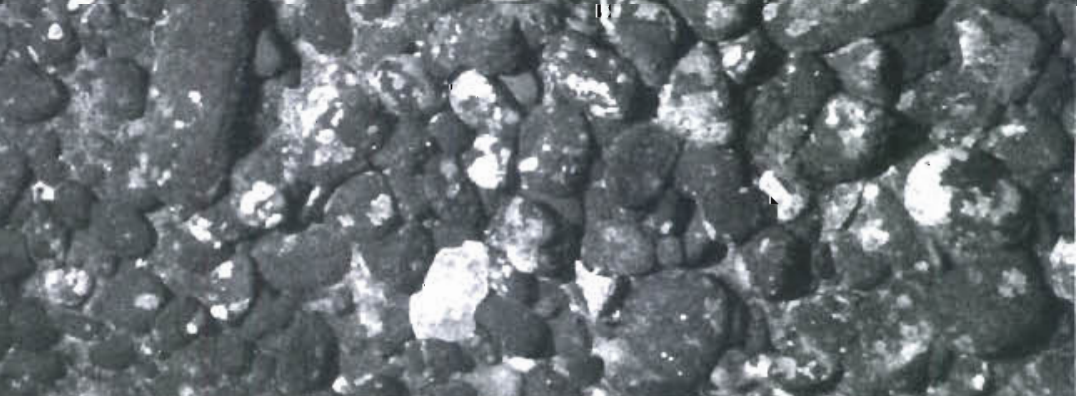


Table 2. Summary of 3-way ANOVAs of ecological indices calculated from dredge samples collected on northern Georges Bank.

Total number of observations was 50. LSM: least square mean; CV: coefficient of variation; MSE: mean squared error; $p>F$ : probability of $F$ larger than the given value

\begin{tabular}{|c|c|c|c|c|c|}
\hline \multirow[b]{3}{*}{ Source } & \multicolumn{5}{|c|}{ Dependent variable: Box-Cox transformation $(\lambda=0.125)$ of abundance $\left(\mathrm{m}^{-3}\right)$} \\
\hline & \multirow[t]{2}{*}{$r^{2}=0.915$} & \multirow{2}{*}{$\begin{array}{c}C V=7.772 \\
\text { df }\end{array}$} & \multicolumn{2}{|c|}{ Root $\mathrm{MSE}=1.196$} & \multirow{2}{*}{$\begin{aligned} \text { Mean } & =15.389 \\
p & >F\end{aligned}$} \\
\hline & & & Type III SS & $F$ & \\
\hline \multicolumn{2}{|l|}{ Depth } & 1 & 237.052 & 165.69 & 0.0001 \\
\hline \multicolumn{2}{|c|}{ Dredge level } & 1 & 118.087 & 82.54 & 0.0001 \\
\hline \multicolumn{2}{|c|}{ Depth $\times$ Dredge level } & 1 & 28.985 & 20.26 & 0.0001 \\
\hline \multicolumn{2}{|c|}{ Cruise } & 1 & 0.001 & 0.00 & 0.9837 \\
\hline \multicolumn{2}{|c|}{ Depth $\times$ Cruise } & 1 & 11.381 & 7.95 & 0.0073 \\
\hline \multicolumn{2}{|c|}{ Dredge level $\times$ Cruise } & 1 & 4.608 & 3.22 & 0.0799 \\
\hline \multicolumn{2}{|c|}{ Depth $\times$ Dredge level $\times$ Cruise } & 1 & 1.447 & 1.01 & 0.3203 \\
\hline Depth & LSM & Dredge level & LSM & Cruise & LSM \\
\hline Deep & 16.326 & Disturbed & 12.140 & April & 13.868 \\
\hline Shallow & 11.418 & Undisturbed & 15.604 & November & 13.876 \\
\hline \multicolumn{6}{|c|}{ Dependent variable: Box-Cox transformation $(\lambda=0.5)$ of biomass $\left(\mathrm{g} \mathrm{m}^{-3}\right)$} \\
\hline \multirow[b]{2}{*}{ Source } & $r^{2}=0.725$ & $\mathrm{CV}=22.424$ & \multicolumn{2}{|c|}{ Root MSE $=44.341$} & Mean $=197.738$ \\
\hline & & df & Type III SS & $F$ & $\mathrm{p}>F$ \\
\hline \multicolumn{2}{|c|}{ Depth } & 1 & 74461.963 & 36.71 & 0.0001 \\
\hline \multicolumn{2}{|c|}{ Dredge level } & 1 & 42433.778 & 20.92 & 0.0001 \\
\hline \multicolumn{2}{|c|}{ Depth $\times$ Dredge level } & 1 & 298.157 & 0.15 & 0.7034 \\
\hline \multicolumn{2}{|c|}{ Cruise } & 1 & 12.747 & 0.01 & 0.9372 \\
\hline Depth $x$ & & 1 & 13525.536 & 6.67 & 0.0134 \\
\hline Dredge & & 1 & 1296.733 & 0.64 & 0.4285 \\
\hline Depth $x$ & Cruise & 1. & 4677.417 & 2.31 & 0.1364 \\
\hline Depth & LSM & Dredge level & LSM & Cruise & LSM \\
\hline Deep & 214.313 & Disturbed & 137.979 & April & 171.385 \\
\hline Shallow & 127.318 & Undisturbed & 203.652 & November & 170.246 \\
\hline & Deper & ariable: Shanno & er $\log _{2}$-abund & Ased diversity & \\
\hline & $r^{2}=0.705$ & $\mathrm{CV}=9.672$ & Roo & 0.327 & Mean $=3.382$ \\
\hline Source & & $d f$ & Type III SS & $F$ & $p>F$ \\
\hline Depth & & 1 & 9.295 & 86.88 & 0.0001 \\
\hline Dredge & & 1 & 0.544 & 5.08 & 0.0295 \\
\hline Depth $x$ & & 1 & 0.371 & 3.47 & 0.0697 \\
\hline Cruise & & 1 & 0.136 & 1.27 & 0.2660 \\
\hline Depth $x$ & & 1 & 0.066 & 0.61 & 0.4382 \\
\hline Dredge? & & 1 & 0.336 & 3.14 & 0.0838 \\
\hline Depth $x$ & ruise & 1 & 0.025 & 0.23 & 0.6304 \\
\hline Depth & LSM & Dredge level & LSM & Cruise & LSM \\
\hline Deep & 3.703 & Disturbed & 3.100 & April & 3.158 \\
\hline Shallow & 2.731 & Undisturbed & 3.335 & November & 3.276 \\
\hline & Depen & ariable: Evennes & rsity index bas & bundance & \\
\hline & $r^{2}=0.347$ & $C V=9.157$ & Root & 0.067 & Mean $=0734$ \\
\hline Source & & $\mathrm{df}$ & Type III SS & $F$ & $p>F$ \\
\hline Depth & & 1 & 0.008 & 0.84 & 0.3640 \\
\hline Dredge & & 1 & 0.071 & 7.64 & 0.0084 \\
\hline Depth $x$ & & 1 & 0.055 & 5.92 & 0.0193 \\
\hline Cruise & & 1 & 0.010 & 1.11 & 0.2988 \\
\hline Depth $x$ & & 1 & 0.007 & 0.81 & 0.3744 \\
\hline Dredge 1 & & 1 & 0.015 & 1.59 & 0.2138 \\
\hline Depth $x$ & ruise & 1 & 0.003 & 0.29 & 0.5944 \\
\hline Depth & LSM & Dredge level & LSM & Cruise & LSM \\
\hline Deep & 0.450 & Disturbed & 0506 & April & 0.448 \\
\hline Shallow & 0.478 & Undisturbed & 0.421 & November & 0.480 \\
\hline
\end{tabular}


tial variability in dredging effort within a $10^{\prime}$ quadrant. Nevertheless, the differences in dredging effort are consistent with our interpretation of the sonograms and bottom photographs. The 6 sites were classified as deep or shallow and as disturbed or undisturbed (Table 1) to be amenable to analysis of variance.

Distance dredged for our scientific samples ranged from 4 to $86 \mathrm{~m}$ and was difficult to determine accurately. The volume of sediment collected ranged from 18 to 364 l. We chose to standardize the abundance and biomass by volume of sediment collected because, at almost all stations, it resulted in a lower coefficient of variation than standardizing by area. An 8th-root transformation was applied to the abundance data, and a square-root transformation to the biomass data, prior to calculating the ANOVA. Variances of all the ecological indices were homogeneous, according to Bartlett's test. Initial 1-way ANOVAs provided Duncan Groupings (Dowdy \& Wearden 1991) of the ecological indices from each station: there were no significant differences between stations from the same site.

The numerical abundance of organisms was significantly greater at the deep sites and significantly greater at the undisturbed sites (Table 2, Fig. 3). There was, however, a significant interaction between depth and dredging level, because the difference between disturbed and undisturbed sites was greater at 80 than at $40 \mathrm{~m}$. The depth $x$ cruise interaction was significant because the depth effect on abundance was greater in November than April. Results were the same whether the data from the 2 cruises were analyzed separately or together; the cruise (season) effect was insignificant. Biomass was significantly greater at the deep sites and was significantly greater at the undisturbed sites (Table 2, Fig. 4). Results were the same whether the biomass data were analyzed together or for each cruise separately. The cruise effect was insignificant but there was a significant depth $\times$ cruise interaction, again because the depth effect was greater in November than April.

Species diversity was significantly greater at depth and at the undisturbed sites (Table 2, Fig. 5). The cruise effect on diversity was insignificant but the depth $x$ dredge level and dredge level $x$ cruise interactions were significant at $p=0.1$. The dredging effect on diversity was significant in April 1994 but not in November 1994. This is because species diversity at undisturbed Site 10 apparently declined while diversity at disturbed Site 13 increased between the 2 cruises. Evenness was significantly greater at disturbed sites than undisturbed sites; it was not significantly different between depths or cruises (Table 2, Fig. 6). There was a significant interaction between the effects of depth and dredge level. The dredging effect on evenness was significant in November 1994 but not in April 1994 when Site 18 had a higher mean evenness than Site 17 Disturbed Site 13 had consistently high evenness, which indicates that the organisms were more evenly distributed among the species present. The evenness index helps explain the changes in species diversity at Sites 10 and 13 from April to November. Diversity declined at Site 10, not because of fewer species but because the organisms were less evenly distributed among the species. Conversely, diversity increased at Site 13 because evenness increased.

We were unable to perform an ANOVA on the species richness measure because of large differences in the total numbers of organisms in samples collected at disturbed $(\min .=64)$ and undisturbed sites $(\max .=$ 3372). The minimum sample size defines the maximum number of individuals at which rarefaction curves can be compared. At small numbers of individuals the curves intersect, obscuring the differences in species
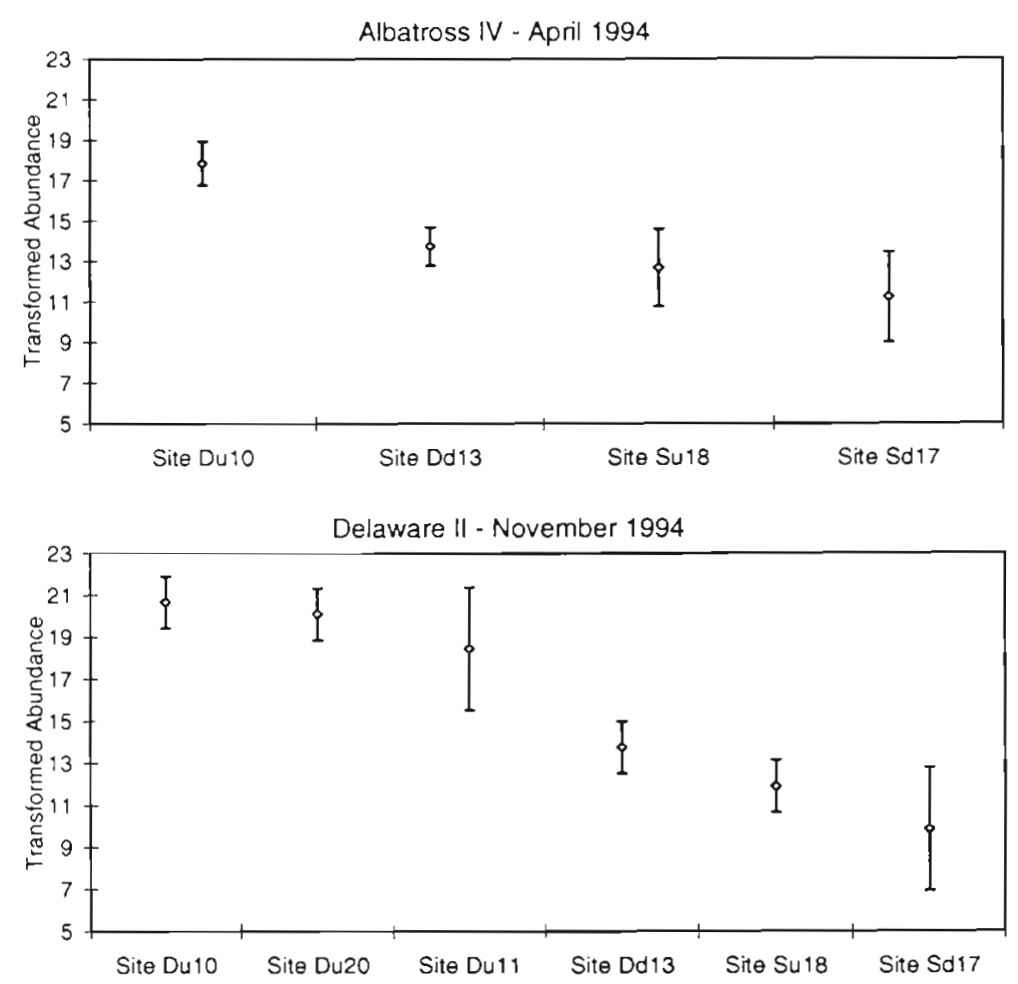

Fig. 3. Numerical abundance of benthic megafauna from northeastern Georges Bank. Box-Cox transformation $(\lambda=0.125)$ was applied to density $\mathrm{m}^{-3}$ Symbols represent means and $95 \%$ confidence intervals. Site identifiers: D, Deep; S, Shallow; u, undisturbed; d, disturbed 


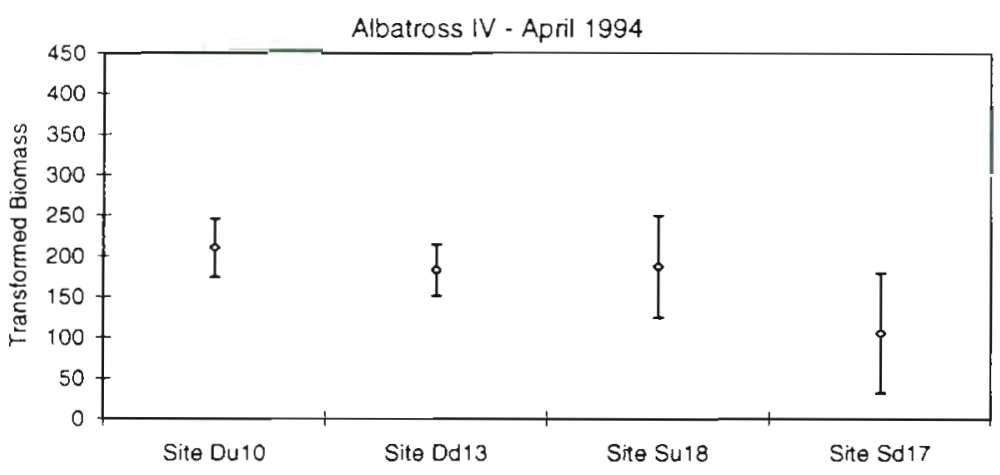

and species groups form a block pattern of presence and absence. The species were separated into 7 main groups with 4 levels of clustering Species in the first group occurred almost exclusively at the deep sites, both disturbed and undisturbed. These species were mainly hard-shelled molluscs Natica clausa and Astarte spp. and crabs Pagurus pubescens and Hyas coarctatus. The second group consisted of species mostly found at the deep, undisturbed sites. This group was characterized by the polychaetes Thelephus cincinnatus,

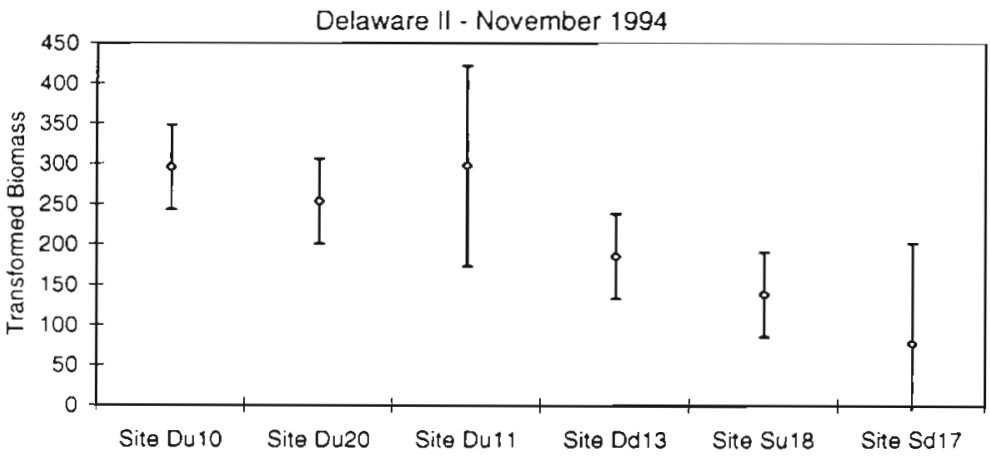
Eunice norvegica, Chone infundibuli= formis and Protula tubularia, the shrimps Lebbeus groenlandicus and Spirontocaris lilljeborgii and the brittle star Ophiopholis aculeata, many of which were found living between the tubes of Filograna implexa. This group also included numerous molluscs: Musculus discors, Calliostoma occidentale, Chlamys islandicus, Sinum perspectivum, and Cerastoderma pinnulatum.

Group 3 contained 6 species that were

Fig. 4. Biomass of benthic megafauna from northeastern Georges Bank. Box-Cox transformation $(\lambda=0.5)$ was applied to $\mathrm{g} \mathrm{m}^{-3}$. Symbols represent means and $95 \%$ confidence intervals. Site identifiers as in Fig. 3 abundant at the undisturbed sites and rare or absent from the disturbed sites. These species included shrimps Eualus pusiolus

richness among sites. Therefore, species richness is illustrated with rarefaction curves for each site (Fig. 7). The rarefaction curves were calculated from only 1 station at each site, because the total numbers of individuals collected exceeded the maximum dimensions of Krebs (1989) rarefaction program. The rarefaction curves indicate that species richness was higher at the deep sites and higher at undisturbed than at disturbed sites. This pattern in species richness was the same for the 4 sites sampled on both cruises. Species richness at Site 11 was considerably lower than at the other 2 deep, undisturbed sites (Sites 10 and 20) Overall species diversity at Site 11 was as high as at Sites 10 and 20 because Site 11 had higher evenness.

The program TWINSPAN produces a 2 way classification of the samples by species, and species by sample (Table 3). The group classification of the 50 samples corresponded almost exactly to the sampling sites. The first level of clustering was for depth and the second for disturbance level. Site 10 separated from Sites 11 and 20 at the third level of clustering The sample
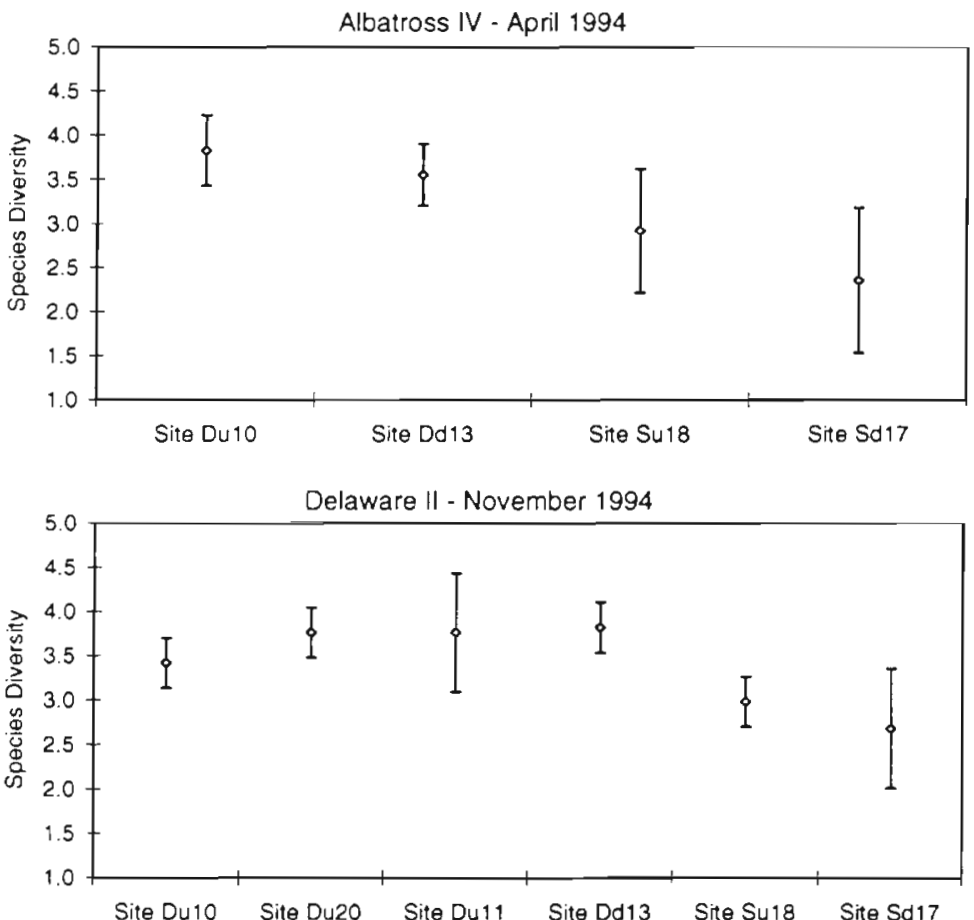

Fig. 5 Shannon-Wiener diversity index of benthic megafauna, based on $\log _{2}$ of numerical abundance. Symbols represent means and $95 \%$ confidence intervals. Site identifiers as in Fig. 3 
and Pandalus montagui, the horse mussel Modiolus modiolus, and the bloodstar Henricia sanguinolenta. Group 4 was a group of mixed species that were abundant everywhere except the shallow, disturbed site. The fifth group comprised species that were ubiquitous: the sea scallop Placopecten magellanicus, the whelk Buccinum undatum, and the sea urchin Strongylocentrotus droebachiensis. Species in group 6 occurred at all sites but were more abundant at the undisturbed ones. This group is characterized by small fish Myoxocephalus spp. and Liparis atlanticus, shrimps Dichelopandalus leptocerus and Crangon septemspinosa, and polychaetes Nereis zonata and Harmothoe imbricata. The seventh group contained species that were more abundant at the shallow sites, in addition to occurring at the deep sites. This group consisted mainly of predators and scavengers: Asterias vulgaris, Cancer irroratus, Pagurus acadianus, Neptunea decemcostata and Colus spp.

The size-frequency distributions of the following species differed significantly among sites as measured with the Kolmogorov-Smirnov test: Astarte subaequilatera, A. undata, Strongylocentrotus droebachiensis, and Asterias vulgaris. However, there was no consistent pattern in size distributions with depth, dredging level, or between cruises. Some of the significant size differences are likely due to chance sample variability, because we made multiple pairwise comparisons. The Acadian hermit crab Pagurus acadianus was the only species for which there was a significant size difference that was consistent between cruises (Fig. 8): larger $P$. acadianus were found at the deep disturbed site (Site 13) than at the deep undisturbed site (Site 10).

\section{DISCUSSION}

We have documented a gradient in community structure from deep, undisturbed sites to shallow, disturbed sites. The deep, undisturbed sites had higher abundance of organisms, biomass and species diversity (Figs. 3 to 5). Disturbed sites had a higher evenness diversity (Fig. 6), possibly because dredging prevents any one species from becoming numerically dominant. In general, the individual mean weight of organisms was greater at the deep, disturbed site (Site 13) than at the deep, undisturbed site (Site 10). This finding does not support the hypothesis of a shift in size structure toward larger individuals in undisturbed areas (ICES 1994). Relatively large, thick-shelled gastropods were abundant at Site 13, and their shells harboured larger hermit crabs than at Site 10 .

In particular, the mean size of Pagurus acadianus was larger at Site 13 than at Site 10 (Fig. 8). It is possible that the larger $P$. acadianus migrated into the disturbed areas to feed on animals that were damaged by scallop dredging. A congeneric hermit crab $P$. bernhardus had a similar short-term response to beam trawling in the Irish Sea (Ramsay et al. 1996). After fishing, greater numbers and larger sizes of $P$. bernhardus were found on the treatment line than on unfished control transects. Interestingly, no response to beam trawling was observed for the sympatric hermit crab $P$. prideaux. Likewise in our study, the abundance or size of the congener $P$. pubescens did not differ between disturbed and undisturbed sites. The different responses of the Pagurus species to bottom-fishing disturbance could result from either competitive interactions or niche separation (Ramsay et al. 1996).

Many of the species that were absent or less common at disturbed Site 13 are small, fragile polychaetes shrimps and brittle stars (Table 3). The deep, undisturbed sites are characterized by the presence of colonies of the tube-dwelling polychaete, Filograna implexa, bushy bryozoans and hydroids. This epifauna provides small, mobile animals a complex habitat that is almost entirely absent at the disturbed site (Site 13). Our finding is consistent with a study of the tube epi- 


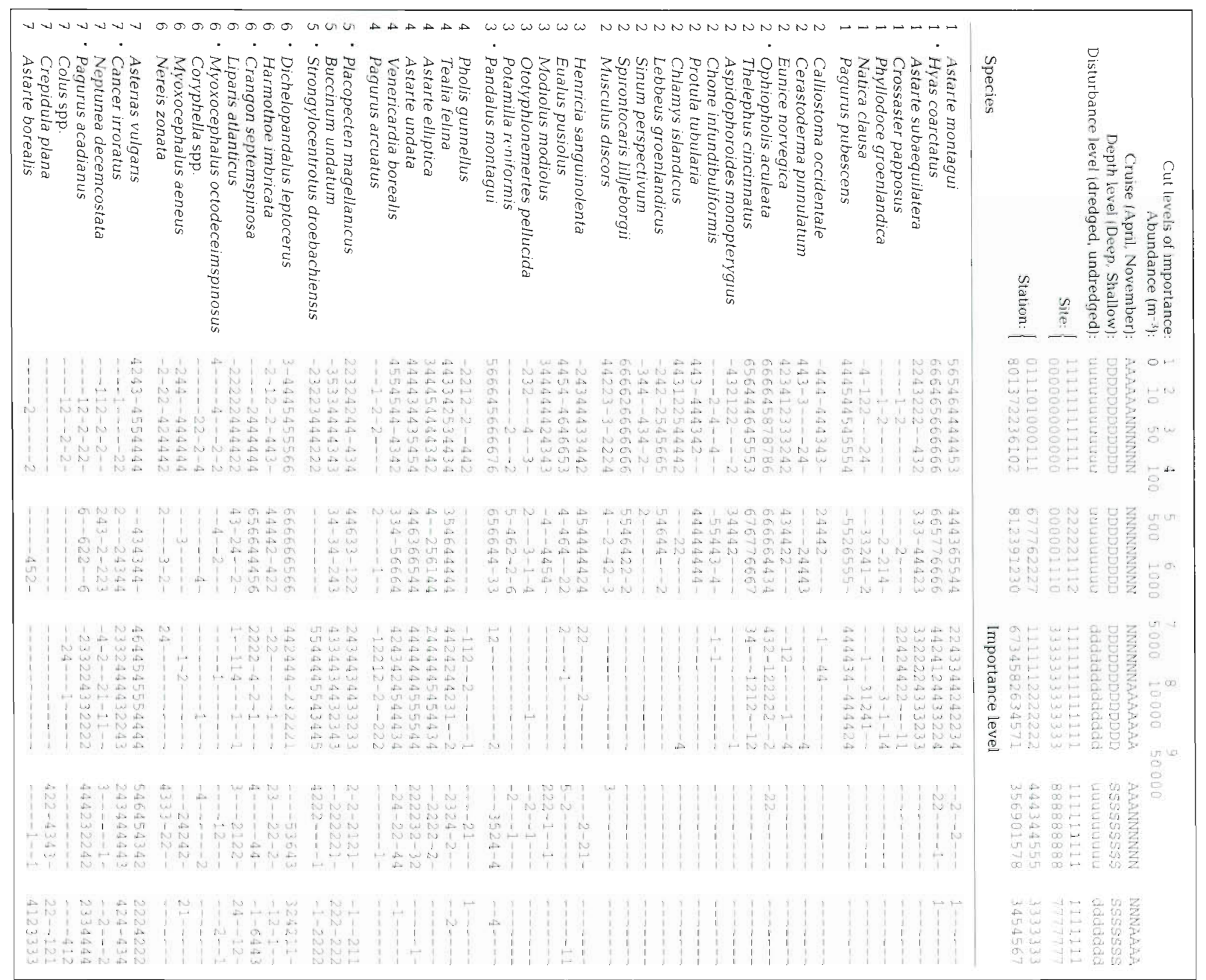

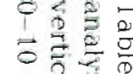

5. 른

흘

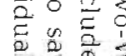

का 0

等

$5 \rightarrow$ ?

을

o 5.

눙

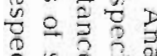

硡

zo

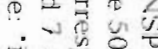

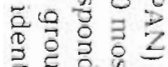

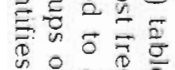

는

证

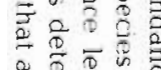

눙

5 .

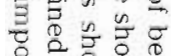

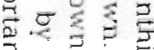

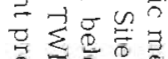

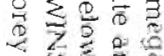

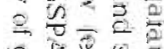

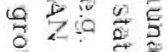

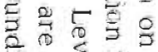

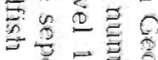

굴

的

2.

足

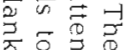


fauna of the polychaete Phyllochaetopterus socialis on a rocky shore in Brazil (Nalesso et al. 1995). As in our study, the tube epifauna was dominated by ophiuroids, crustacea and polychaetes. Nalesso et al. (1995) noted that the intricate tube structure of $P$. socialis accumulates organic material, favoring the establishment of detritivores such as ophiuroids

Mussels and a group of small molluscs were absent or rare at Site 13, probably because they are sensitive to the physical effects of dredging In contrast, the thick-shelled bivalves Astarte subaequilatera and A. montagui, gastropods Buccinum undatum, Neptunea decemcostata and Natica clausa and hermit crabs Pagurus spp. were numerous both at the disturbed and undisturbed sites; these species are presumably resistant to dredging. The sea scallop Placopecten magellanicus was more abundant at the deep sites irrespective of the degree of dredging. Of course, as $P$. magellanicus is the target of dredging in this area, commercial dredging would not occur at sites not inhabited by sea scallops. We cannot infer the effects of physical disturbance on $P$. magellanicus from our samples alone because its abundance is also affected by direct fishery removals and by differences in exploitation rate in the U.S. and Canadian zones. Small fish Aspidophoroides monopterygius, Liparis atlanticus and Myoxocephalus spp. were more abundant at the undisturbed sites, possibly because of the shelter provided by the epifauna at these sites. The few invertebrate taxa that were abundant at the shallow, disturbed site (Site 17) are mainly predators and scavengers (Table 3).

Our results are consistent with a prior, broad survey of the megabenthos of eastern Georges Bank. Thouzeau et al. (1991b) identified 2 habitat types on the lag pebble/gravel deposits that correspond to our study area. They defined biogenic bottom as a mixture of sand, gravel, cobble and tubes of Filograna implexa. Their second type, gravel habitat, consisting of pebbles with cobbles and boulders, is similar to the first without the biogenic cover Thouzeau et al. (1991b) attributed the scarcity of epibenthic sessile taxa on the coarse sediments of northern Georges Bank to heavy fishing, but did not attempt to identify fished and unfished sites. Based on our results, we would classify Thouzeau et al.'s (1991b) biogenic habitat as undisturbed and their gravel habitat as disturbed. In their study, the biogenic bottom had higher species richness, abundance and biomass; dominant species were the mollusc Astarte spp. and the brittlestar Ophiopholis aculeata.
As in our study, the dominant species on the gravel habitat were the echinoderms Strongylocentrotus droebachiensis and Asterias vulgaris. According to Thouzeau et al. (1991b), the heterogeneous sediments and polychaete tubes of the biogenic bottom provide spatial refuges from predators and suitable microhabitats for invertebrates, especially juveniles. Sandy patches between gravel particles harbor infaunal bivalves. Mobile polychaetes were more abundant on the biogenic bottom because of the increased habitat complexity.

Ten of the species in Table 3 have been identified as important prey of Georges Bank groundfish (Bowman \& Michaels 1984) Two of these species, Strongylocentrotus droebachiensis and Cancer irroratus, were ubiquitous at our study sites. Three prey species, Dichelopandalus leptocerus, Hyas coarctatus and Placopecten magellanicus, occurred at all sites but were more abundant at depth, irrespective of the degree of dredging. Pagurus acadianus, an important prey of Raja erinacea, Gadus morhua and Urophysis chuss, was more abundant at the shallow sites, both disturbed and undisturbed. The other 4 prey species, Crangon 


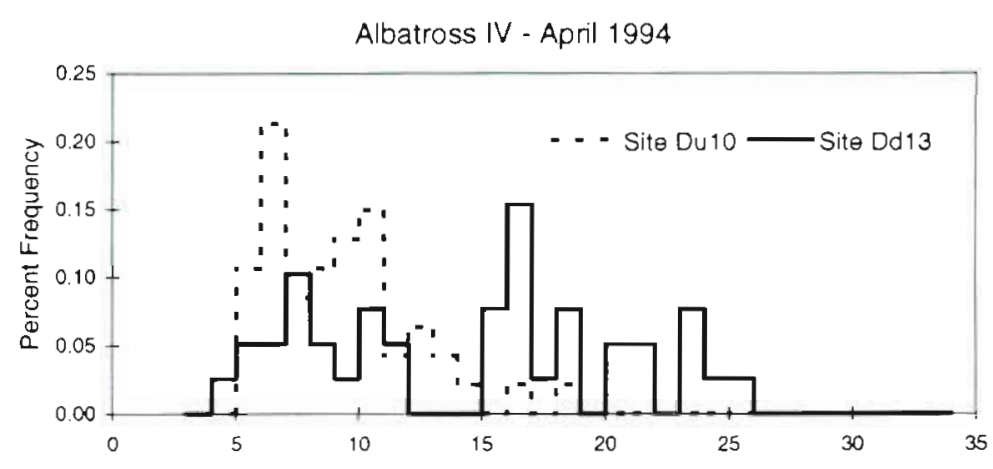

Delaware II - November 1994

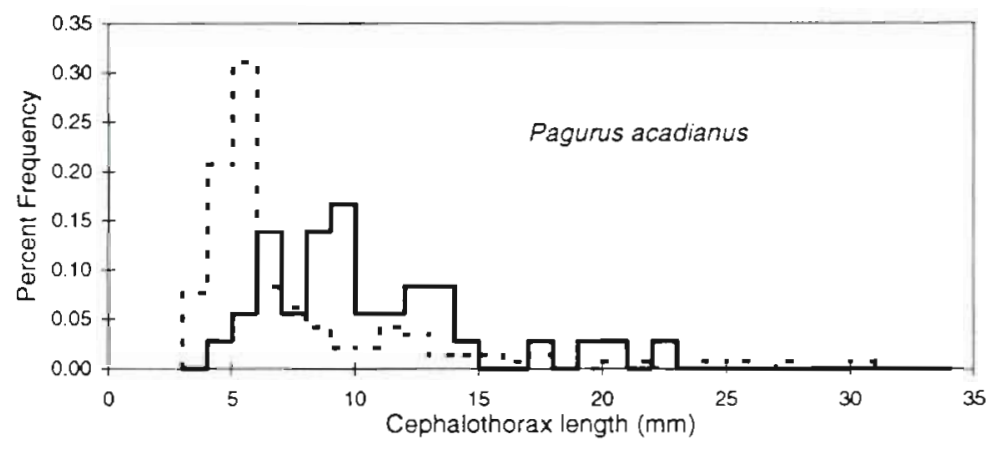

Fig. 8. Size-frequency distributions of the Acadian hermit crab Pagurus acadianus from 2 deep sites in the Canadian zone. These samples had significant differences $(p=0.05)$ in the size distributions between disturbed and undisturbed sites, according to the Kolmogorov-Smurnov 2sample test. Site identifiers as in Fig. 3

septemspinosa, Pandalus montagui, Ophiopholis aculeata and Myoxocephalus octodecemspinosus, were most abundant at the deep, undisturbed sites. Demersal fish collected randomly with respect to habitat are more likely to have eaten prey species that are ubiquitously distributed. However, our results suggest that dredging could adversely affect the abundance of some preferred prey species.

The results of this study must be qualified with several caveats. The Naturalists' dredge is considered to be a semi-quantitative sampler (Eleftheriou \& Holme 1984). Despite the differential GPS navigation, our estimates of arca dredged were imprecise. The ratio of sediment volume to area dredged differed considerably between sites and cruises, indicating that the penetration of the dredge into the gravel was not constant. By standardizing the counts and biomass to the more quantitative measure of sediment collected rather than area dredged, we were able to obtain relatively low coefficients of variation among replicate samples.

We attribute the differences in community structure between sites to the effects of depth and dredging disturbance. One reason for the impoverished fauna at the shallow sites may be that strong tidal currents prevent settlement of planktonic larvae. All our sampling sites were deliberately located on gravel deposits, but there may have been subtle differences in sediment grain size between sites, which could affect community structure. There is also an interaction between grain size and dredying. Fishermen avoid areas with scattered boulders, even though these cover a small fraction of the bottom $(<5 \%)$. Large cobbles and boulders are removed by fishermen from areas of active dredging, resulting in a more homogeneous pebble/cobble bottom such as at Sites 13 and 17

For the purposes of our study, we deliberately sought contrasting sites and classified them as either disturbed or undisturbed. In reality there was a gradient in dredging disturbance from the least disturbed (Site 20) to the most heavily disturbed site (Site 17). Additionally, the spatial distribution of dredging effort shifts over time. In November 1994 more dredge scars were apparent at Site 10 than in April 1994 Conversely, at Site 18, we suspect that the epifaunal community was recovering from previous dredging disturbance.

Based on the sizes $(-10 \mathrm{~cm})$ and complexity of epifaunal taxa at undisturbed sites, we speculate that the time scales of disturbance and recovery are on the order of 5 to 10 yr Georges Bank has been dredged for scallops for decades; the limited amount of dredging we observed at Site 10 was apparently insufficient to have affected the community structure. Recovery of the attached epifauna to its natural condition may take many years. Direct experimentation is required to unequivocally demonstrate the effects of fishing disturbance on benthic communities. Our most heavily disturbed site in the U.S. zone (Site 17) was closed to all bottom fishing in December 1994 as part of emergency groundfish conservation measures. This unplanned experiment has provided an excellent opportunity to monitor the recovery of a previously disturbed site.

Despite the qualifications discussed above, bottom fishing is the most likely explanation of the differences between sites at each depth. In this study we quantified the differences in the non-colonial taxa sampled with a Naturalists' dredge. The most apparent difference between sites is the lack of colonial, epifaunal taxa at the disturbed sites. These taxa are not quantitatively sampled by the Naturalists' dredge and were therefore not included in this analysis. Frame-byframe analysis of the epifauna in bottom videos and still photographs taken on these 2 cruises is the subject of another paper (Collie et al. 1996). 
Acknowledgements. Kurt Maekawa and Greg Fronczek helped sort and identify the samples. An earlier draft of this paper was presented as a working document at the ICES Working Group on Ecosystem Effects of Fishing Activities meeting in Copenhagen in March 1996. We thank Michel Kaiser for his thorough review of the working document and John Allen for helping to identify species of the genus Astarte. Funding was provided by the NOAA/URI Cooperative Marine Education and Research Program, award no. NA37FE0433, the U.S. Geological Survey, Cooperative Research Agreement 1434-HQ-96-AG-01533, and the National Undersea Research Center, project number UCAP96-06

\section{LITERATURE CITED}

Alexander AB, Moore HF, Kendall WC (1914) Otter-trawl fishery. Report of the US Commissioner of Fisheries, Appendix VI

Auster PJ, Malatesta RJ, Langton RW, Watling L, Valentıne PC, Donaldson CS, Langton EW, Shepard AN, Babb IG (1996) The impacts of mobile fishing gear on low topography benthic habitats in the gulf of Mainc (northwest Atlantic): implications for conservation of fish populations. Rev Fish Sci 4(2):185-202

Bowman RE, Michaels WL (1984) Food of seventeen species of northwest Atlantic fish. NOAA Tech Memorandum NMFS-F/NEC-28

Bradstock M, Gordon DP (1983) Coral-like bryozoan growths in Tasman Bay, and their protection to conserve commerClal fish stocks. NZ J Mar Freshwater Res 17:159-163

Buzas MA, Gibson TG (1969) Species diversity: benthic Foraminifera in the western North Atlantic. Science 163: $72-75$

Caddy JF (1973) Underwater observations on tracks of dredges and trawls and some effects of dredging on a scallop ground. J Fish Res Bd Can 30:173-180

Churchill JH (1989) The effect of commercial trawling on sediment resuspension and transport over the Middle Atlantic bight continental shelf. Cont Shelf Res 9:841-864

Collie JS, Escanero G. Hunke L, Valentine PC (1996) Scallop dredging on Georges Bank: photographic evaluation of effects on benthic epifauna. ICES Comm Meet 1996/ Mini: 9

De Groot SJ (1984) The impact of bottom trawling on benthic fauna of the North Sea. Ocean Manage 9:177-190

Dowdy S, Wearden S (1991) Statistics for research, 2nd edn. Wiley, New York

Eleftheriou A, Holme NA (1984) Macrofauna techniques. In: Holme NA, McIntyre AD (eds) Methods for the study of marne benthos, 2nd edn. IBP Handbook 16, Blackwell, Oxford, p 140-216

Graham M (1955) Effect of trawling on animals of the sea bed Deep Sea Res 3 (Suppl): $1-6$

Hill MO (1979) TWINSPAN-a FORTRAN program for arranging multivariate data in an ordered two-way table by classification of individuals and attributes. Ecology and Systematics, Cornell University, Ithaca

International Council for the Exploration of the Sea (1994) Report of the ICES working group on ecosystem effects of fishing activities. ICES Comm Meet 1994/ASSESS/ENV:1

Johnson RA, Wichern DW (1992) Applied multivariate analysis, 3rd edn. Prentice Hall, Englewood Cliffs, NJ

Jones JB (1992) Environmental impact of trawling on the sea bed: a review. NZ J Mar Freshwater Res 26:59-67

Kaiser MJ, Spencer BE (1996) The effects of beam-trawl dis- turbance on infaunal communties in different habitats. J Anim Ecol 65:348-358

Krebs CJ (1989) Ecological methodology. Harper Collins, New York

Langton RW, Auster PJ, Schneider DC (1995) A spatial and temporal perspective on research and management of groundfish in the northwest Atlantic. Rev Fish Sci 3: $210-229$

Langton RW, Robinson WE (1990) Fauna) associations on scallop grounds in the wostern Gulf of Maine. J Exp Mar Biol Ecol 144:157-171

Lough RG, Valentine PC, Potter DC, Auditore PJ, Boltz GR, Neilson JD. Perry RI (1989) Ecology and distribution of juvenile cod and haddock in relation to sediment type and bottom currents on eastern Georges Bank. Mar Ecol Prog Ser 56:1-12

Messieh SN, Rowell TW, Peer DL, Cranford PJ (1991) The effects of trawling, dredging and ocean dumping on the eastern Canadian continental shelf seabed. Cont Shelf Res 11:1237-1263

Moody JA, Butman B, Beardsley RC, Brown WS, Daifuku P Irish JD, Mayer DA, Mofjeld HO, Petrie B, Ramp S, Smith P, Wright WR (1984) Atlas of tidal elevation and current observations on the northeast American continental shelf and slope. US Geol Surv Bull 1611

Nalesso RC, Duarte LFL, Pierozzi 1, Enumo EF (1995) Tube epifauna of the polychaete Phyllochaetopterus socialis Claparède. Estuar Coast Shelf Sci 41:91-100

National Research Council (NRC) (1995) Understanding marine biodiversity: a research agenda for the nation National Academy Press, Washington, DC

Peterson CH, Summerson HC, Fegley SR (1987) Ecological consequences of mechanical harvesting of clams. Fish Bull US 85:281-298

Ramsay K, Kaiser MJ, Hughes RN (1996) Changes in hermit crab feeding patterns in response to trawling disturbance. Mar Ecol Prog Ser 144:63-72

Reise K (1982) Long-term changes in the macrobenthic inver tebrate fauna of the Wadden Sea: are polychaetes about to take over? Neth J Sea Res 16:29-36

Riemann B, Hoffmann E (1991) Ecological consequences of dredging and bottom trawling in the Limfjord, Denmark Mar Ecol Prog Ser 69:171-178

Samsbury KJ (1988) The ecological basis of multuspecies fisheries and managment of a demersal fishery in tropical Autralia. In: Gulland JA (ed) Fish population dynamics, 2nd edn. John Wiley \& Sons, London, p 349-382

Schwinghamer P. Guigné JY, Siu WC (1996) Quantufying the impact of trawling on benthic hubitat using high resolution acoustics and chaos theory. Can J Fish Aquat Sci 53: $288-296$

Sokal RP, Rohlf FS (1981) Biometry. Freeman, San Francisco

Thouzeau G, Robert G, Smıth SJ (1991a) Spatıal variability in distribution and growth of juvenile and adult sea scallops Placopecten magellanucus (Gmelin) on eastern Georges Bank (Northwest Atlantıc). Mar Ecol Prog Ser 74:205-218

Thouzeau G, Robert G, Ugarte R (1991b) Faunal assemblages of benthic megainvertebrates inhabiting sea scallop grounds from eastern Georges Bank, in relation to environmental factors. Mar Ecol Prog Ser 74:61-82

Thrush SF, Hewitt JE, Cummings VJ, Dayton PK (1995) The impact of habitat disturbance by scallop dredging on marine benthic communities: what can be predicted from the results of experiments? Mar Ecol Prog Ser 129:141-150

Valentine PC, Lough RG (1991) The influence of geological and oceanographic environmental factors on the abundance and distribution of fisheries resources of the north- 
eastern United States continental shelf. The sea floor environment and the fishery of eastern Georges Bank. OpenFile Report 91-439, US Geol Surv

Valentine PC, Strom EW, Lough RG, Brown CL (1993) Maps showing the sedimentary environment of eastern Georges

This artucle was presented by Kenneth Sherman (Senior Editorlal Advisor), Narragansett, Rhode Island, USA
Bank. US Geol Surv Misc Invest Ser, Map I-2279-B, scale 1:250000

Van Dolah RF, Wendt PH, Nichoison N (1987) Effects of research trawls on hard-bottom assemblages of sponges and corals. Fish Res 5:39-54

Manuscript received: December 4, 1996

Revised version accepted: June 6, 1997 